\title{
Estrogen-like activity of aqueous extract from Agrimonia pilosa Ledeb. in MCF-7 cells
}

\author{
Young Min Lee ${ }^{1 *}$, Jung Bong Kim¹, Ji Hyun Bae', Jong Suk Lee², Pan-Soo Kim², Hwan Hee Jang ${ }^{1}$ \\ and Haeng Ran Kim ${ }^{1}$
}

\begin{abstract}
Background: Postmenopausal women experience estrogen deficiency-related menopausal symptoms (e.g., hot flashes and mood swings) and a dramatic increase in the incidence of chronic diseases. Although estrogen-replacement therapy (ERT) can reduce mortality from cardiovascular disease and improve osteoporosis and menopausal symptoms, its side effects have limited recent use. This study investigated the estrogen-like activity of aqueous extract from Agrimonia pilosa Ledeb.
\end{abstract}

Methods: The estrogenic activity of A. pilosa was investigated by using several in vitro assays. The binding activity of A. pilosa on estrogen receptors was examined using a fluorescence polarization-based competitive binding assay. The proliferative activity of A. pilosa was also examined using MCF-7 cells. Furthermore, the effect of A. pilosa on the expression of 3 estrogen-dependent genes was assessed.

Results: Using liquid chromatography-mass spectrometry, the 3 major peaks of A. pilosa aqueous extract were identified as apigenin-hexose, luteolin-glucuronide, and apigenin-glucuronide. The aqueous extract induced the proliferation of estrogen receptor-positive MCF-7 cells $(p<0.05)$. A. pilosa-stimulated proliferation was blocked on adding the estrogen antagonist ICI 182,780. Moreover, A. pilosa treatment increased the mRNA expression of the estrogen-responsive genes PS2 and PR $(p<0.05)$.

Conclusions: These results suggest $A$. pilosa can be used to improve estrogen deficiency-related menopausal symptoms or to treat diseases in postmenopausal women.

Keywords: MCF-7 proliferation assay, Estrogenic activity, Agrimonia pilosa, Metabolic syndrome

\section{Background}

Postmenopausal women experience estrogen deficiencyrelated menopausal symptoms, including hot flashes, mood swings, and sweating [1]. Postmenopausal women also exhibit a dramatic increase in the risk of metabolic syndrome, cognitive deficits, cardiovascular disease, dyslipidemia, and osteoporosis [2-5]. As the population ages and life expectancy increases, the importance of preventing and/or improving menopause-related changes has become paramount [6].

Hormone replacement therapy (HRT) can reduce mortality from cardiovascular disease and improve osteoporosis and menopausal symptoms [7]. In addition, Daly

\footnotetext{
* Correspondence: ymlee@korea.kr

${ }^{1}$ Functional Food \& Nutrition Division, Department of Agro-food Resources, National Academy of Agricultural Science, Rural Development

Administration, Suwon, Republic of Korea

Full list of author information is available at the end of the article
}

et al. reported that quality of life significantly improved after HRT [8]. However, many studies have shown that HRT is no longer a good solution for the treatment of menopausal women because of the increased risk of breast and endometrial cancers associated with longterm estrogen-replacement therapy (ERT) $[9,10]$.

Phytoestrogens, that is, plant-derived estrogens, are found naturally in a diverse range of foods and include isoflavones, lignans, coumestans, and flavonoids (e.g., quercetin and kaempferol). Because the structure of phytoestrogens is similar to that of human estrogen, phytoestrogens can bind to estrogen receptors (ERs) [11]. Much scientific effort has been put into the search for additional phytoestrogens showing estrogen-like activity, leading to the continuous discovery of novel phytoestrogens in nature $[12,13]$.

\section{Biomed Central}

(C) 2012 Lee et al.; licensee BioMed Central Ltd. This is an Open Access article distributed under the terms of the Creative Commons Attribution License (http://creativecommons.org/licenses/by/2.0), which permits unrestricted use, distribution, and reproduction in any medium, provided the original work is properly cited. 
Agrimonia pilosa Ledeb. is a medicinal plant with anti-cancer [14], anti-oxidant [15], acetylcholinesterase inhibitory [16], and anti-inflammatory activities [17,18]. Some chemical studies have reported that A. pilosa contains phenolic compounds such as agrimonin, catechin, quercetin, and rutin $[19,20]$. However, the estrogenic effects of aqueous extract from $A$. pilosa have not yet been examined.

The purpose of this study was to investigate the estrogenic activity of $A$. pilosa by using several in vitro assays. The binding activity of $A$. pilosa on estrogen receptors was examined using a fluorescence polarization-based competitive binding assay. The proliferative activity of $A$. pilosa was also examined using MCF-7 cells. Furthermore, the effect of $A$. pilosa on the expression of 3 estrogen-dependent genes was assessed.

\section{Methods}

Plant material and extraction

The aerial parts of $A$. pilosa were purchased from Kyungdong Market (Seoul, Korea) in dried form and identified by the Classification and Identification Committee of the Korea Institute of Oriental Medicine (KIOM). A voucher specimen (KIOM109-122Aa) has been deposited at the herbarium of the Department of Herbal Resources Research of the KIOM. Each of the dried components was extracted twice with 10 volumes of water at $80^{\circ} \mathrm{C}$ for $3 \mathrm{~h}$. The extracts were filtered through filter paper (Whatman, Maidstone, UK) and were concentrated under reduced pressure by a rotary evaporator (EYELA, Tokyo, Japan) at $40^{\circ} \mathrm{C}$. The water filtrates were frozen and lyophilized. The lyophilized extracts were stored at $-20^{\circ} \mathrm{C}$ until use.

\section{Analysis of $A$. pilosa aqueous extract composition}

The chemical composition of the A. pilosa aqueous extract was determined using liquid chromatography-mass spectrometry (LC-MS). Briefly, aqueous extracts of $A$. pilosa were subjected to ultra-high performance liquid chromatography-mass spectrometry (UHPLC-MS) analysis. LC-MS was performed using a LTQ Orbitrap XL linear ion trap mass spectrometer system (Thermo Fisher Scientific Co., Waltham, MA) equipped with an electrospray ionization source. The UHPLC separations were performed with an Accela UHPLC system (Thermo Fisher Scientific) by using an Acquity BEH C18 column (1.7 $\mu \mathrm{m}, 100 \times 2.1 \mathrm{~mm}$; Waters Corp., Milford, MA). Mobile phase A was water and phase B was acetonitrile, where both phases contained $0.1 \%$ formic acid. The gradient elution, at a flow rate of $0.3 \mathrm{~mL} / \mathrm{min}$, was performed as follows: $0-1 \mathrm{~min}, 1 \% \mathrm{~B}$ (isocratic); $1-15 \mathrm{~min}$, 1-30\% B (linear gradient); 15-20 min, 30-60\% B (linear gradient); $20-25 \mathrm{~min}, 60-100 \% \mathrm{~B}$ (linear gradient); and 25-27 min 100\% B (isocratic). Full-scan mass spectra were obtained using the negative-ion mode at with an $m / z$ range of $100-1000$. Data-dependent tandem mass spectrometry (MSn) experiments were controlled by menu-driven software provided with the Xcalibur system (Thermo Fisher Scientific).

\section{ERa- and ER $\beta$-binding assays}

Estrogen receptor-binding ability was examined using an estrogen receptor (ER) competitive binding assay kit (Invitrogen, Carlsbad, CA) according to the manufacturer's instructions. The relative affinity of the test material for ER was determined by the change in polarization value (Molecular Devices Inc., Sunnyvale, $\mathrm{CA})$ in the presence of a test plant.

\section{Cell culture}

MCF-7, an ER-positive human breast cancer cell line, was purchased from the Korean Cell Line Bank (Seoul, Korea) and cultured in RPMI-1640 containing 10\% fetal bovine serum and penicillin-streptomycin solution (100 units/mL penicillin and $100 \mu \mathrm{g} / \mathrm{mL}$ streptomycin; Hyclone Laboratories, Inc., South Logan, UT). The cells were grown at $37^{\circ} \mathrm{C}$ in a humidified atmosphere of $95 \%$ air $/ 5 \% \mathrm{CO}_{2}$. The medium was renewed 2-3 times per week, and before reaching confluence, the cells were subcultured every 3-4 days in a 1: 4 ratio.

\section{Proliferation assay of MCF-7 cells (E-screen assay)}

Confluent MCF-7 cells were washed twice with phosphate-buffered saline (PBS) (Hyclone Laboratories) and $0.05 \%$ trypsin-EDTA solution (Invitrogen) was added for $1 \mathrm{~min}$. After trypsin-EDTA was removed, the culture was left at room temperature $\left(\sim 20^{\circ} \mathrm{C}\right)$ for $5-$ $10 \mathrm{~min}$; subsequently, the cells were detached, resuspended in RPMI-1640 medium, counted, and seeded into 24-well plates at a density of $2 \times 10^{4}$ cells/well in normal growth medium. After $24 \mathrm{~h}$, the cells were completely attached to the well bottom; the medium was then aspirated and estrogen-free medium containing both phenol-red-free RPMI (Invitrogen) and 5\% charcoal-dextran-stripped human serum (Hyclone Laboratories) was added. MCF-7 cells were treated with different concentrations of test material and were cultured for $144 \mathrm{~h}$. In addition, test material were added to the medium at some concentrations where they showed estrogenic activity, either with or without the ER-antagonist ICI 182,780 (Tocris, Bristol, UK). $17 \beta$-Estradiol and PBS were used as the positive and negative controls, respectively.

\section{MTT proliferation assay}

Cell proliferation was assessed after $7 \mathrm{~d}$ in culture, using the MTT proliferation assay. After the incubation period, cells were added with $100 \mu \mathrm{L}$ of $5 \mathrm{mg} / \mathrm{mL}$ 
thiazolyl blue tetrazolium bromide (Sigma, St. Louis, MO) solution/well and were incubated further for $4 \mathrm{~h}$ in a humidified atmosphere $\left(37^{\circ} \mathrm{C}\right.$ in $\left.5 \% \mathrm{CO}_{2}\right)$. The medium was replaced with $1 \mathrm{~mL}$ dimethyl sulfoxide (DMSO). The absorbance was measured at $540 \mathrm{~nm}$ in a microplate reader (Molecular Devices Inc., Sunnyvale, CA). Cell proliferation was expressed as percentage values compared with the negative PBS control, which was considered to represent $100 \%$ cell proliferation.

\section{RNA isolation}

MCF-7 cells were seeded in $75-\mathrm{cm}^{2}$ culture flasks at a density of $2 \times 10^{4}$ cells $/ \mathrm{cm}^{2}$ in RPMI-1640 medium and incubated at $37^{\circ} \mathrm{C}$ at $5 \% \mathrm{CO}_{2}$. On the following day, the medium was shifted to estrogen-free medium containing phenol-red-free RPMI (Invitrogen) and 5\% charcoaldextran-stripped human serum (Hyclone Laboratories) with controls or test material. After the cells were incubated for $24 \mathrm{~h}$ at $37^{\circ} \mathrm{C}$ and $5 \% \mathrm{CO}_{2}$, they were washed twice with PBS, and total RNA was extracted from cells using the RNeasy Plus Mini Kit (Qiagen, Venlo, Netherlands), according to the manufacturer's protocol. The quantity and purity of the total RNA obtained were determined on the basis of the absorbance at 260 and $280 \mathrm{~nm}$. RNA quality was determined by gel electrophoresis on $2 \%$ agarose gels stained with ethidium bromide $(0.5 \mu \mathrm{g} / \mathrm{mL})$. RNA samples were stored at $-20^{\circ} \mathrm{C}$ until use.

\section{Real-time RT-PCR}

The expression levels of estrogen-dependent genes were determined by a real-time one-step RT-PCR performed using the SYBR Green PCR master mix (Qiagen) and a thermal cycler Rotor-Gene 3000 (Corbett Research, Mortlake, Australia), in accordance with the manufacturer's protocol. The primer sequences for glyceraldehyde-3phosphate dehydrogenase (GAPDH), pS2, progesterone receptor (PR), and cathepsin D are as follows (forward and reverse, respectively):

GAPDH: 5'-CCATGGAGAAGGCTGGGG-3', 5'-CA AAGTTGTCATGGATGACC-3'; pS2: 5'-CATCGACGT CCCTCCAGAAGAG-3', 5'-CTCTGGGACTAATCAC CGTGCTG-3'; PR: 5'-CGCGCTACCCTGCACTC-3', 5'-TGAATCCGGCCTCAGGTAGTT-3'; and cathepsin D: $5^{\prime}$-CTGAGCAGGGACCCAGATG-3', $5^{\prime}$-CAGGTG GACCTGCCAGTAG-3'.

One step RT-PCR was performed as follows: (1) reverse transcription at $50^{\circ} \mathrm{C}$ for $30 \mathrm{~min}$; (2) initial denaturation at $95^{\circ} \mathrm{C}$ for $15 \mathrm{~min}$; and (3) 40 cycles of denaturation at $95^{\circ} \mathrm{C}$ for $30 \mathrm{~s}$, annealing at $60^{\circ} \mathrm{C}$ for $30 \mathrm{~s}$, and elongation at $72^{\circ} \mathrm{C}$ for $30 \mathrm{~s}$. Melting-curve analysis was performed at $72-95^{\circ} \mathrm{C}$ to verify the specificity of amplification and was supplemented with $2 \%$ agarose gel electrophoresis of randomly selected samples. The relative quantitation values were calculated by analyzing the changes in SYBR Green fluorescence during PCR, according to the manufacturer's instructions. $C_{t}$ values were defined as the threshold cycles at which a statistically significant increase occurred in the intensity of SYBR Green emission. Using the $2^{-\Delta \Delta C t}$ method, the changes (in orders of magnitude) relative to the control were calculated. $C_{t}$ values were normalized to those for the housekeeping gene, GAPDH and the $\Delta \mathrm{C}_{\mathrm{t}}$ values of the $A$. pilosa-treated cells were normalized to the mean $\Delta C_{t}$ values of the controls.

\section{Statistical analysis}

Data was expressed as mean \pm SD values. Cell proliferation was expressed as percentage values compared with that for the negative PBS control, which was taken to represent $100 \%$ cell proliferation. Duncan's multiple range tests were used to detect differences between groups when analysis of variance was significant at $p<$ 0.05 . Student's $t$-test was used to establish significant differences between any 2 groups.

\section{Results}

HPLC analysis of $A$. pilosa aqueous extract for constituent flavonoids

A. pilosa aqueous extract was examined for its flavonoid composition by simultaneous estimation using negative ion-mode tandem mass analysis $\left(\mathrm{MS}^{2}\right.$ and $\left.\mathrm{MS}^{3}\right)$. Individual constituents were identified by analysis of the $\mathrm{MS}^{2}$ and $\mathrm{MS}^{3}$ tandem mass spectrum (Figure 1). The 3 major peaks of the $A$. pilosa aqueous extract were identified as apigenin-hexose $\left([\mathrm{M}-\mathrm{H}]^{-}, m / z 449.3\right)$ at an RT of 10.62 min, luteolin-glucuronide $\left([\mathrm{M}-\mathrm{H}]^{-}, m / z 461.3\right)$ at an RT of $11.39 \mathrm{~min}$, and apigenin-glucuronide ([M-H $]^{-}, \mathrm{m} / z$ 445.3) at an RT of $12.62 \mathrm{~min}$. The sugar moiety was defined by $\mathrm{MS}^{2}$ fragment ion analysis. The aglycone structure of $\mathrm{MS}^{3}$ spectra was identified by an MS/MS spectrum library search [21]. The percentage content of each flavonoid was estimated with the relative peak area based on PDA (200-500 nm) data. The flavonoids present in the extract included apigenin-glucuronide (21.81\%), apigenin-hexose (19.46\%), and luteolinglucuronide (13.03\%).

\section{Competitive binding of $A$. pilosa to estrogen receptors}

To evaluate the estrogenic activity of the aqueous extract from A. pilosa, the ability of $A$. pilosa to bind ER $\alpha$ and $\mathrm{ER} \beta$ was assessed using a competitive binding assay based on fluorescence polarization. As shown Figure 2, this aqueous extract could bind ERs and displaced E2bound $E R \alpha$ and $E R \beta$. 


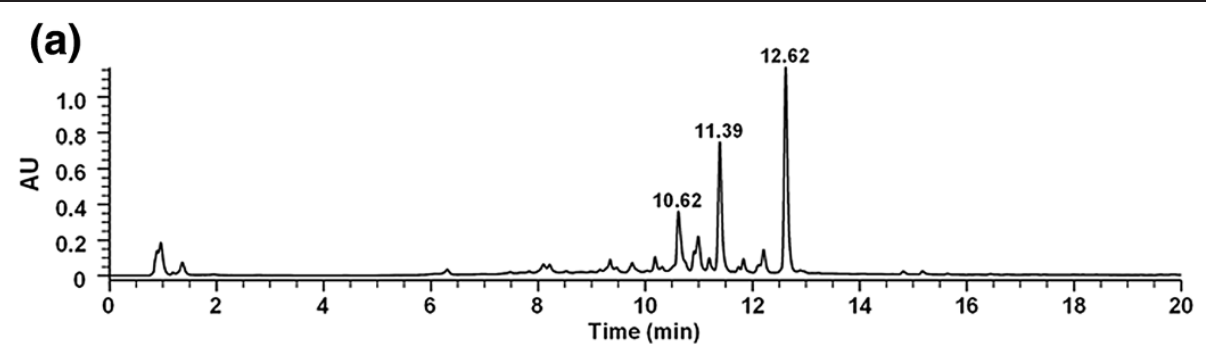

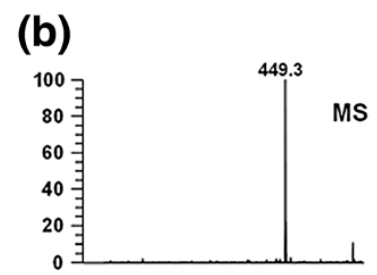

(c)
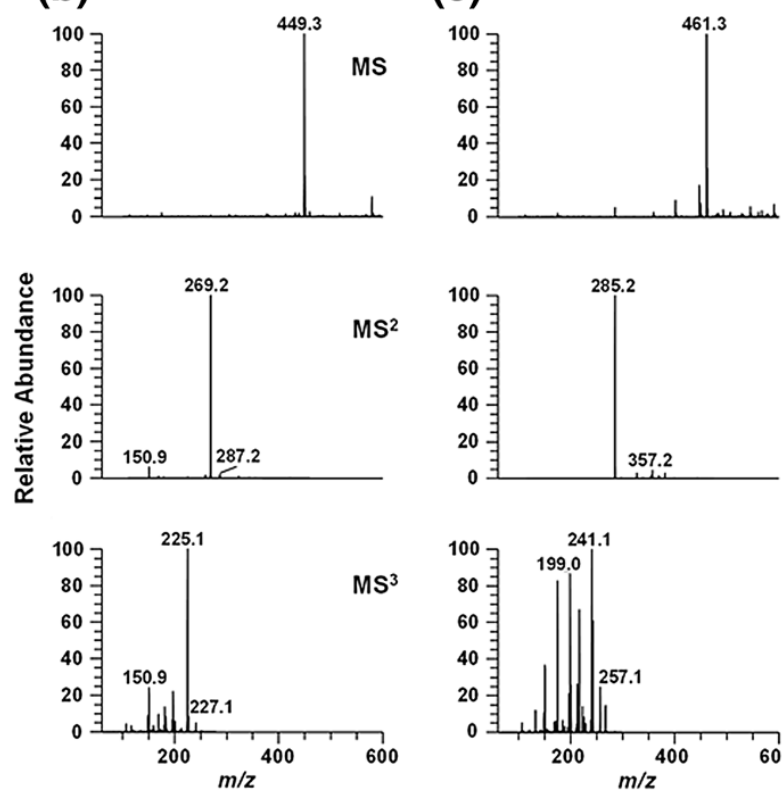

(d)
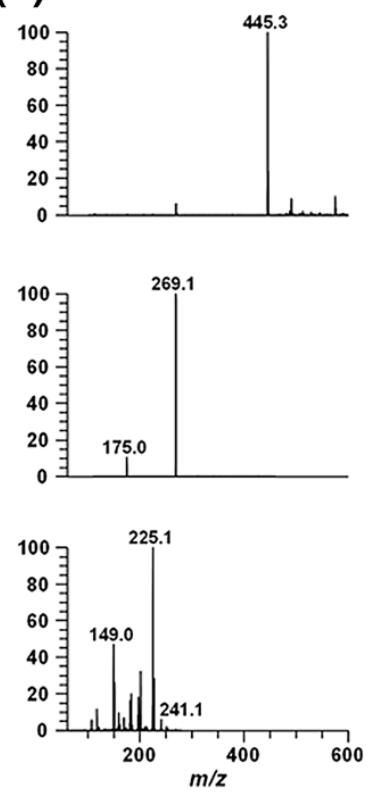

Figure 1 Results of UPLC-MS analysis of the 3 main compounds of $\boldsymbol{A}$. pilosa aqueous extract. (a) Chromatogram at $350 \mathrm{~nm}$, (b) mass spectrum of apigenin-hexose ([M-H], $\mathrm{m} / \mathrm{z} 449.3)$ at an RT of $10.62 \mathrm{~min}$, (c) luteolin-glucuronide ([M-H]', m/z 461.3) at an RT of $11.39 \mathrm{~min}$, and (d) apigenin-glucuronide ([M-H]', $\mathrm{m} / \mathrm{z} 445.3)$ at an RT of $12.62 \mathrm{~min}$.

Effect of A. pilosa on MCF-7 cell proliferation

In the E-SCREEN assay using MCF-7 cells, the proliferative effect of the aqueous extracts from A. pilosa was evaluated relative to that of the negative control (PBS; Figure 3). As a positive control, the estrogenic effect of $17 \beta$-estradiol on the proliferation in MCF-7 cells was measured. 17 $\beta$-Estradiol caused significant proliferation in MCF-7 cells at concentrations of $10^{-10}-10^{-8} \mathrm{M}$ without cytotoxic activity $(p<0.001)$, and the highest proliferative effect was observed at $10^{-9} \mathrm{M}$. A. pilosa induced significant stimulation of MCF-7 cell proliferation at concentrations of 1 and $10 \mu \mathrm{g} / \mathrm{mL}(p<0.001)$. When $A$. pilosa extracts were co-treated with E2, A. pilosa did not antagonize E2 activity in MCF-7 cells (Figure 4).

\section{ER-dependent action of $A$. pilosa in MCF-7 cells}

To investigate whether the MCF-7 cell proliferation induced by $A$. pilosa is mediated via the ER, cells were incubated with aqueous extract from $A$. pilosa in the presence or absence of the estrogen antagonist, ICI
182,780 (100 nM). The proliferation induced by A. pilosa and E2 was blocked by addition of ICI 182,780 (Figure 5) indicating an ER-dependent mechanism for the estrogenic effects on MCF-7 cell proliferation.

\section{Effect of A. pilosa on the mRNA levels of estrogen- dependent genes}

Three estrogen-dependent genes, pS2, PR, and cathepsin $\mathrm{D}$, in MCF-7 cells were selected for investigating the $A$. pilosa-induced transcriptional response through ER binding. These genes are rapidly and strongly induced by estrogens and indicate estrogenic activity [13,22,23]. Furthermore, these genes are expressed in the MCF-7 breast cancer cells used in the current study and are regulated by estrogen [24-26]. As shown in Figure 6, estrogen induced pS2 ( $>3$-fold), PR ( $>8$-fold), and cathepsin D ( $>2$-fold) gene expression with respect to the control. A. pilosa treatment also elicited an increase in the mRNA expression of pS2, PR, and cathepsin D, 

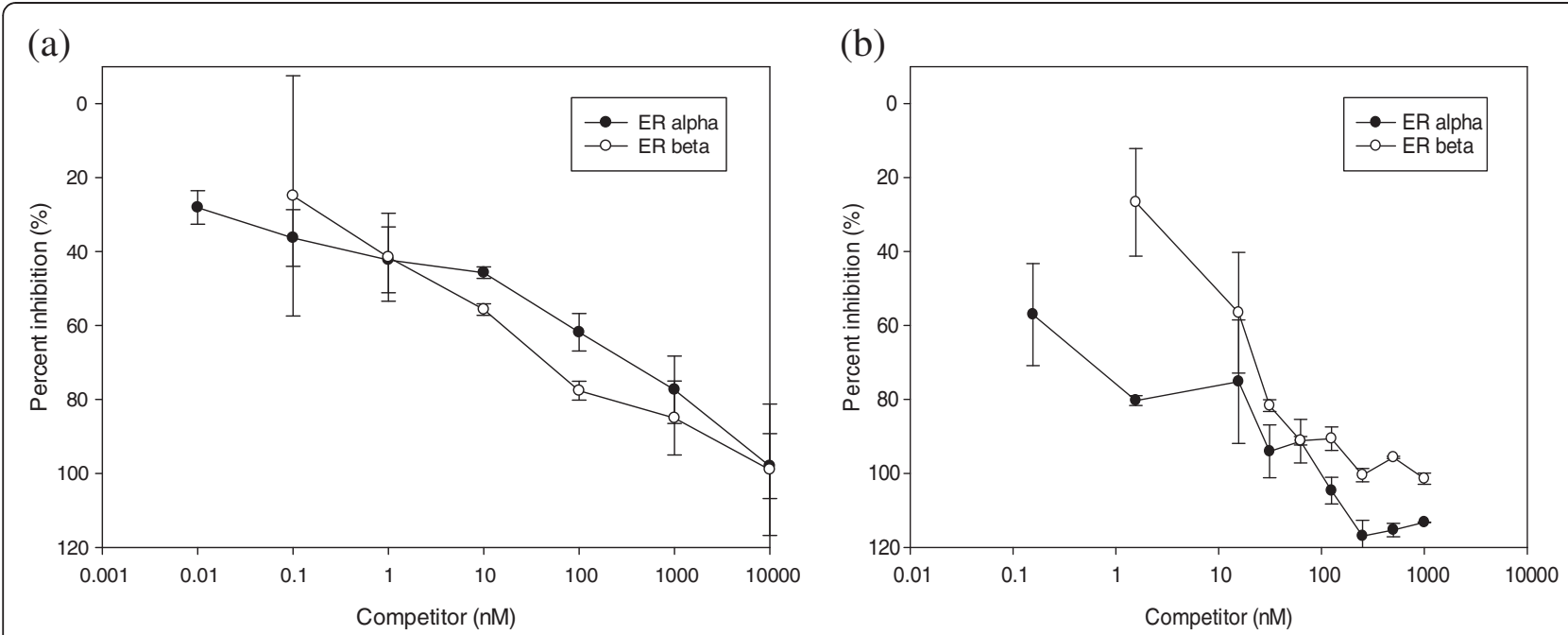

Figure 2 Competitive binding curves illustrating the binding of $\boldsymbol{A}$. pilosa to ERa and ER $\boldsymbol{\beta}$. The results are expressed as mean \pm SD values. (a) The binding affinity of $E 2$ to ERa and ER $\beta$, and (b) the binding affinity of A. pilosa to ERa and ER $\beta$.

resulting in 2- to 6-fold higher expression than that of the control.

\section{Discussion}

Recent concerns have been raised regarding the side effects of the prolonged use of ERT, including an increased risk of breast and endometrial cancers. As a result, research focused on identifying natural agents with estrogen-like activity for the treatment of estrogen deficiency has increased. In light of this increased interest, dozens of edible wild plants have been screened with the goal of identifying estrogenic activity as a part of the search for new phytoestrogens. Of the plants tested, aqueous extracts from the aerial parts of $A$. pilosa have demonstrated estrogenic activity. A. pilosa is a traditional medicinal plant possessing anti-carcinogenic properties, anti-oxidant, and anti-inflammatory properties, and acetylcholinesterase inhibitory effects. However, little is known about the estrogenic activity of the $A$. pilosa aqueous extract.

Since the first step in the activation of ERs involves the binding of a ligand, measurement of ligand binding is important in characterizing the potential estrogenicity of test materials [27]. Therefore, the binding affinity of A. pilosa aqueous extract to ERs was first measured, and subsequently, A. pilosa was thought to bind to ERs by displacing E2 binding. The binding of estrogens or selective estrogen-receptor modulators to ERs initiates a molecular signaling cascade resulting in the transcriptional regulation of specific genes and protein synthesis [28]. Next, a proliferation assay was performed to assess the estrogen-like physiologic action of $A$. pilosa aqueous extract. Estrogens are known stimulants of cellular proliferation and the E-Screen assay measures the effects of
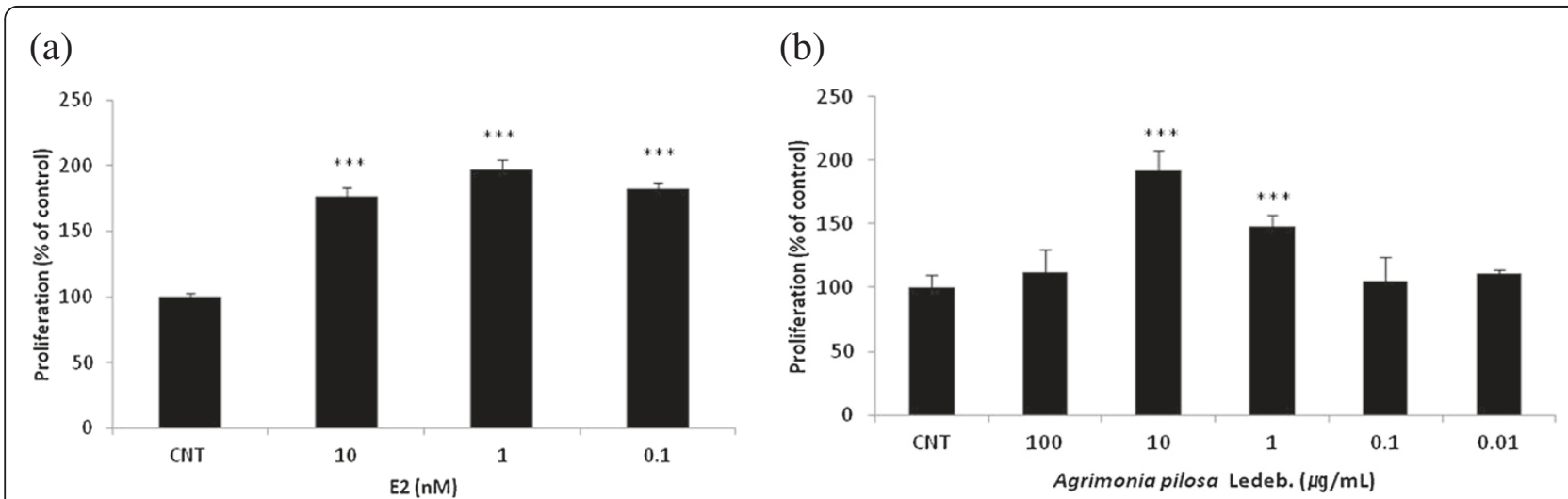

Figure 3 Effect of (a) E2 (17- $\boldsymbol{\beta}$ estradiol) and (b) aqueous extracts of $\boldsymbol{A}$. pilosa on the proliferation of MCF-7 cells. Figures were selected as representative data from three independent experiments. Results are expressed as mean \pm SD values. Statistical significance was determined using the Student's $t$ test. ${ }^{* * *} p<0.001$. 


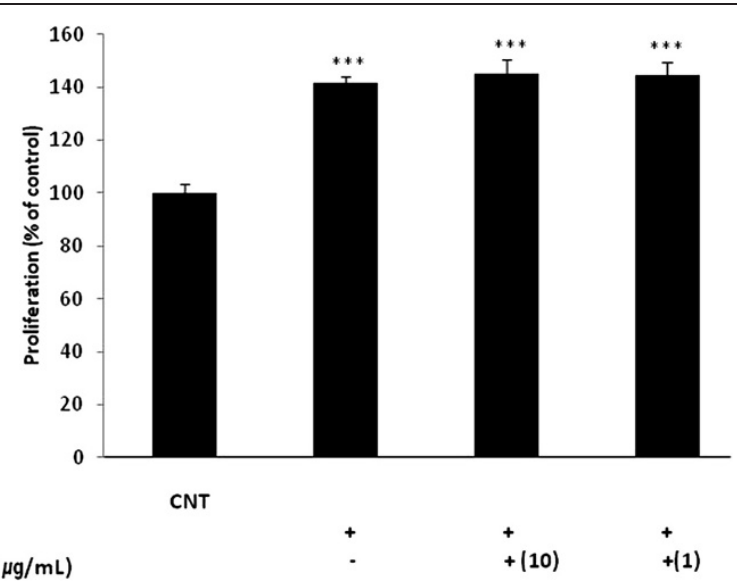

Figure 4 Effect of aqueous extract of Agrimonia pilosa Ledeb. on E2-induced proliferation of MCF-7 cells. Figures were selected as representative data from three independent experiments. Results are expressed as mean \pm SD values. Statistical significance was determined using the Student's $t$-test (*** $p<0.001)$.

a candidate estrogen on cell proliferation in established cell lines, such as MCF-7 [29-31]. The E-Screen assay is one of the most common reliable and valid tests for the physiologic action of estrogen. Finally, the expression of estrogen-related genes may indicate the presence of a functional estrogen signaling pathway $[23,27]$. This assay considers all steps of the ER-signaling pathway, including ER-ligand binding, ER expression, ER dimerization, and available co-activators. Due to the tissue specificity of endogenous ER-regulated gene (or protein) expression, the correct marker should be measured in used cell lines or tissue. In this study, 3 estrogen-dependent genes, pS2, PR, and cathepsin D, were selected to investigate the $A$. pilosa-induced transcriptional response

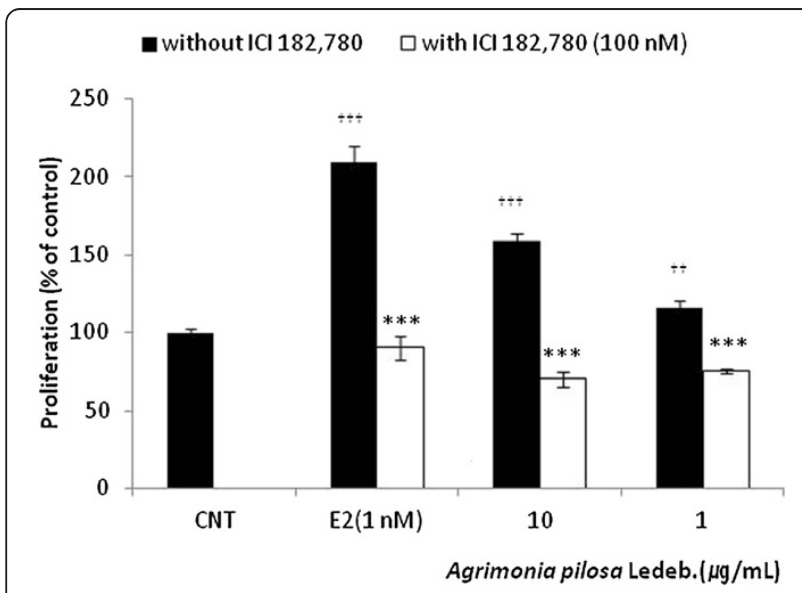

Figure 5 Effect of ICI 182,780 on Agrimonia pilosa Ledeb.induced proliferation in MCF-7 cells. Figures were selected as representative data from three independent experiments. Results are expressed as mean \pm SD values. Statistical significance was determined using the Student's $t$-test. ${ }^{* *} p<0.001$ (vs. without ICl 182,780), ${ }^{+\dagger+} p<0.001,{ }^{+\dagger} p<0.01$ (vs. control). through ER binding. These genes are expressed in MCF7 breast cancer cells used in the present study and are regulated by estrogen, indicating the estrogenic activity of A. pilosa.

Few previous reports have investigated the chemical components of $A$. pilosa. Chemical studies on A. pilosa have shown the presence of polyphenols such as flavonoids [16,32]. Flavonoids and phenolic compounds are known to possess estrogenic activity [33,34]. Therefore, many studies on the estrogenic activity of natural plants attributed their estrogenicity to the presence of flavonoids and phenolic compounds [35,36]. Of the known compounds, the examples of flavonoid phytoestrogens include quercetin, apigenin, and luteolin. In the current study, the flavonoids present in the A. pilosa extract included apigenin-glucuronide (21.81\%), apigenin-hexose (19.46\%), and luteolin-glucuronide (13.03\%). Further

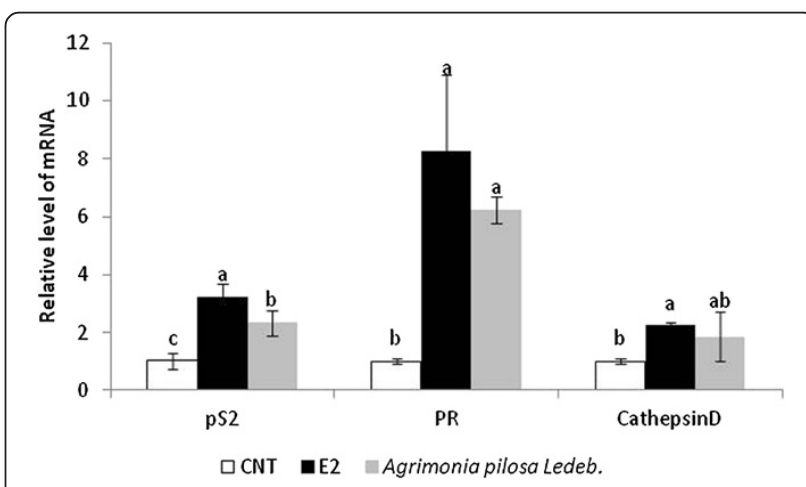

Figure 6 Effect of E2 (1 nM) and Agrimonia pilosa Ledeb. (10 $\mu \mathrm{g} / \mathrm{mL}$ ) on the mRNA levels of estrogen-dependent genes.

Figures were selected as representative data from three independent experiments. Results are expressed as mean \pm SD values. Statistical significance was determined using ANOVA followed by a Duncan's multiple range test $(p<0.05)$. 
investigations to isolate and characterize the estrogenic constituents of $A$. pilosa are underway.

Phytoestrogen was found to show biphasic modulation with regard to MCF-7 cell proliferation. While genistein stimulates cell proliferation and induces the estrogen-regulated end product pS2 at low concentrations ( $1 \mathrm{pM} / \mathrm{nM})$, inhibition of cell growth by ERindependent cellular mechanisms is observed at higher concentrations $(>10 \mathrm{nM})$ [37]. Similarly, an abundant steroidal saponin in ginseng, ginsenoside Rg1, stimulates ER-dependent human breast cancer cell growth at low, but not high, concentrations [12]. The ethanol extract of Ganoderma lucidum has been reported to show both stimulation $(0.1-10 \mu \mathrm{g} / \mathrm{mL})$ and inhibition $(>10 \mu \mathrm{g} / \mathrm{mL})$ of MCF-7 cell proliferation [38]. In our study, A. pilosa aqueous extract also stimulated MCF-7 cell proliferation at low concentrations $(1-10 \mu \mathrm{g} / \mathrm{mL})$ but not at high concentrations $(100 \mu \mathrm{g} / \mathrm{mL})$ similar to that of other known phytoestrogens.

\section{Conclusions}

In conclusion, to our knowledge, this study is the first to investigate the estrogenic activity of $A$. pilosa aqueous extract by using several in vitro assays in MCF-7 cells. A. pilosa aqueous extract bound to ER $\alpha$ and ER $\beta$. In an MCF-7 cell proliferation assay, A. pilosa stimulated the proliferation of estrogen receptor-positive MCF-7 cells in a dose-dependent manner. Proliferation induced by E2 (1 nM) did not decrease after addition of A. pilosa aqueous extract. The proliferation induced by $A$. pilosa was blocked by addition of the estrogen antagonist, ICI 182,780. Furthermore, A. pilosa treatment increased the mRNA expression of estrogen-responsive genes (pS2 and PR). It was therefore concluded that the agonist effects of $A$. pilosa were primarily mediated through ER. These in vitro results demonstrate for the first time that A. pilosa has potent estrogenic activity and may have beneficial effects for postmenopausal women requiring ERT.

\section{Competing interests}

The authors declare that they have no competing interests.

\section{Authors' contributions}

YML designed the research; YML and JHB conducted research. JBK, JSL and PSK conducted HPLC analysis. YML wrote the paper. HHJ and HRK contributed to study design and data interpretation. All authors read and approved the final manuscript.

\section{Acknowledgements \\ This study was carried out with the support of the Research Program for Agricultural Science \& Technology Development (Project No. PJ008554012012), National Academy of Agricultural Science, Rural Development Administration, Republic of Korea.}

\section{Author details}

${ }^{1}$ Functional Food \& Nutrition Division, Department of Agro-food Resources, National Academy of Agricultural Science, Rural Development Administration, Suwon, Republic of Korea. ${ }^{2}$ Gyeonggi Biocenter, Gyeonggi
Institute of Science and Technology Promotion, Suwon, Gyeonggi-do, Republic of Korea.

Received: 5 October 2012 Accepted: 13 December 2012 Published: 21 December 2012

\section{References}

1. Avis NE, Stellato R, Crawford S, Bromberger J, Ganz P, Cain V, Kagawa-Singer M: Is there a menopausal syndrome? Menopausal status and symptoms across racial/ethnicgroups. Soc Sci Med 2001, 52(3):345-356.

2. Carr MC: The emergence of the metabolic syndrome with menopause. J Clin Endocrinol Metab 2003, 88(6):2404-2411.

3. El-Halawany AM, Chung MH, Ma CM, Komatsua K, Nishihara T, Hattori M: Anti-estrogenic activity of mansorins and mansonones from the heartwood of Mansonia gagei DRUMM. Chem Pharm Bull 2007 55(9):1332-1337.

4. Nordin B, MacGregor J, Smith D: The incidence of osteoporosis in normal women: its relation to age and the menopause. Q J Med 1966, 35(137):25-38.

5. Sherwin BB: Hormones, mood, and cognitive functioning in postmenopausal women. Obstet Gynecol 1996, 87(2):20S-265.

6. Hill K: The demography of menopause. Maturitas 1996, 23(2):113-127.

7. Grady D, Rubin SM, Petitti DB, Fox CS, Black D, Ettinger B, Ernster VL, Cummings SR: Hormone therapy to prevent disease and prolong life in postmenopausal women. Ann Intern Med 1992, 117(12):1016-1037.

8. Daly E, Gray A, Barlow D, McPherson K, Roche M, Vessey M: Measuring the impact of menopausal symptoms on quality of life. BMJ 1993, 307 (6908):836-840.

9. Persson I, Weiderpass E, Bergkvist L, Bergstrom R, Schairer C: Risks of breast and endometrial cancer after estrogen and estrogen-progestin replacement. Cancer Causes Control 1999, 10(4):253-260.

10. Writing Group for the Women's Health Initiative Investigators: Risks and benefits of estrogen plus progestin in healthy postmenopausal women: principal results from the Women's Health Initiative Randomized Controlled Trial. JAMA 2002, 288(3):321-333.

11. Davis SR, Dalais FS, Simpson ER, Murkies AL: Phytoestrogens in health and disease. In Recent Progress in Hormone Research, Proceedings of the 1998 Conference. Volume 54. Edited by Conn PM. 1999:185-211.

12. Chan RYK, Chen WF, Dong A, Guo D, Wong MS: Estrogen-like activity of ginsenoside Rg1 derived from Panax notoginseng. J Clin Endocrinol Metab 2002, 87(8):3691-3695

13. Boué SM, Tilghman SL, Elliott S, Zimmerman MC, Williams K, Payton-Stewart F, Miraflor AP, Howell MH, Shih BY, Carter-Wientjes CH: Identification of the potent phytoestrogen glycinol in elicited soybean (Glycine max). Endocrinology 2009, 150(5):2446-2453.

14. Miyamoto K, Kishi N, Koshiura R: Antitumor effect of agrimoniin, a tannin of Agrimonia pilosa Ledeb., on transplantable rodent tumors. Jpn J Pharmacol 1987, 43(2):187.

15. He C, Ji X, Pan Y, Wang H, Wang K, Liang M, Yang L: Antioxidant activity of alcoholic extract of Agrimonia pilosa Ledeb. Med Chem Res 2010, 19(5):448-461.

16. Jung $M$, Park M: Acetylcholinesterase inhibition by flavonoids from Agrimonia pilosa. Molecules 2007, 12(9):2130-2139.

17. Taira J, Nanbu H, Ueda K: Nitric oxide-scavenging compounds in Agrimonia pilosa Ledeb on LPS-induced RAW264. 7 macrophages. Food Chem 2009, 115(4):1221-1227.

18. Jung $\mathrm{CH}$, Kim JH, Park SJ, Kweon DH, Kim SH, Ko SG: Inhibitory effect of Agrimonia pilosa Ledeb. on inflammation by suppression of iNOS and ROS production. Immunol Invest 2010, 39(2):159-170.

19. Xu X, Qi X, Wang W, Chen G: Separation and determination of flavonoids in Agrimonia pilosa Ledeb. by capillary electrophoresis with electrochemical detection. J Sep Sci 2005, 28(7):647-652.

20. Murayama T, Kishi N, Koshiura R, Takagi K, Furukawa T, Miyamoto K: Agrimoniin, an antitumor tannin of Agrimonia pilosa Ledeb., induces interleukin-1. Anticancer Res 1992, 12(5):1471-1474.

21. Lee JS, Kim DH, Liu KH, Oh TK, Lee CH: Identification of flavonoids using liquid chromatography with electrospray ionization and ion trap tandem mass spectrometry with an MS/MS library. Rapid Commun Mass Spectrom 2005, 19(23):3539-3548. 
22. Yoshida N, Omoto Y, Inoue A, Eguchi H, Kobayashi Y, Kurosumi M, Saji S, Suemasu K, Okazaki T, Nakachi K: Prediction of prognosis of estrogen receptor-positive breast cancer with combination of selected estrogen-regulated genes. Cancer Sci 2004, 95(6):496-502

23. Jorgensen M, Vendelbo B, Skakkebaek NE, Leffers H: Assaying estrogenicity by quantitating the expression levels of endogenous estrogen-regulated genes. Environ Health Perspect 2000, 108(5):403-412.

24. Xing W, Archer TK: Upstream stimulatory factors mediate estrogen receptor activation of the cathepsin D promoter. Mol Endocrinol 1998, 12(9):1310-1321.

25. Nardulli AM, Greene GL, O'Malley BW, Katzenellenbogen BS: Regulation of progesterone receptor messenger ribonucleic acid and protein levels in MCF-7 cells by estradiol: analysis of estrogen's effect on progesterone receptor synthesis and degradation. Endocrinology 1988, 122(3):935-944.

26. El-Tanani MKK, Green CD: Interaction between estradiol and growth factors in the regulation of specific gene expression in MCF-7 human breast cancer cells. J Steroid Biochem Mol Biol 1997, 60(5-6):269-276.

27. Mueller SO: Overview of in vitro tools to assess the estrogenic and antiestrogenic activity of phytoestrogens. J Chromatogr B Analyt Technol Biomed Life Sci 2002, 777(1-2):155-165.

28. Hall JM, Couse JF, Korach KS: The multifaceted mechanisms of estradiol and estrogen receptor signaling. J Biol Chem 2001, 276(40):36869-36872.

29. Rasmussen TH, Nielsen JB: Critical parameters in the MCF-7 cell proliferation bioassay (E-Screen). Biomarkers 2002, 7(4):322-336.

30. Soto AM, Sonnenschein C, Chung KL, Fernandez MF, Olea N, Serrano FO: The E-SCREEN assay as a tool to identify estrogens: an update on estrogenic environmental pollutants. Environ Health Perspect 1995, 103:113-122.

31. Villalobos M, Olea N, Brotons JA, Oleaserrano MF, Dealmodovar JMR, Pedraza V: The E-screen assay: a comparison of different MCF7 cell stocks. Environ Health Perspect 1995, 103(9):844-850.

32. Kato H, Li W, Koike M, Wang Y, Koike K: Phenolic glycosides from Agrimonia pilosa. Phytochemistry 2010, 71(16):1925-1929.

33. Miksicek RJ: Commonly occurring plant flavonoids have estrogenic activity. Mol Pharmacol 1993, 44(1):37-43.

34. Wilkinson $A$, Wähälä K, Williamson G: Identification and quantification of polyphenol phytoestrogens in foods and human biological fluids. J Chromatogr B Analyt Technol Biomed Life Sci 2002, 777(1):93-109.

35. Verhoog NJ, Joubert E, Louw A: Evaluation of the phytoestrogenic activity of Cyclopia genistoides (honeybush) methanol extracts and relevant polyphenols. J Agric Food Chem 2007, 55(11):4371-4381.

36. El-Halawany AM, Chung MH, Nakamura N, Ma CM, Nishihara T, Hattori M: Estrogenic and anti-estrogenic activities of Cassia tora phenolic constituents. Chem Pharm Bull 2007, 55(10):1476-1482.

37. Zava DT, Duwe G: Estrogenic and antiproliferative properties of genistein and other flavonoids in human breast cancer cells in vitro. Nutr Cancer 1997, 27(1):31-40.

38. Shimizu K, Miyamoto I, Liu J, Konishi F, Kumamoto S, Kondo R: Estrogenlike activity of ethanol extract of Ganoderma lucidum. J Wood Sci 2009, 55(1):53-59.

doi:10.1186/1472-6882-12-260

Cite this article as: Lee et al.: Estrogen-like activity of aqueous extract from Agrimonia pilosa Ledeb. in MCF-7 cells. BMC Complementary and Alternative Medicine 2012 12:260.

\section{Submit your next manuscript to BioMed Central and take full advantage of:}

- Convenient online submission

- Thorough peer review

- No space constraints or color figure charges

- Immediate publication on acceptance

- Inclusion in PubMed, CAS, Scopus and Google Scholar

- Research which is freely available for redistribution

Submit your manuscript at www.biomedcentral.com/submit 